\title{
An Old Therapy, Convalescent Plasma, for Coronavirus Disease-19: Do We Have All the Answer?
}

\author{
Ahmad Faried ${ }^{1,2,3 *}$, Wahyu Widowati ${ }^{4}$, Ruswana Anwar ${ }^{3}$, Nucki Nursjamsi Hidajat ${ }^{2}$, Ali Budi Harsono ${ }^{2}$, Yulius Hermanto ${ }^{1,2}$, \\ Alya Mardhotillah Azizah", Jenifer Kiem Aviani ${ }^{5}$ \\ ${ }^{1}$ Department of Neurosurgery, Faculty of Medicine, Universitas Padjadjaran, Dr. Hasan Sadikin Hospital, Bandung, West Java, \\ Indonesia; ${ }^{2}$ Stem Cell Unit, Dr. Hasan Sadikin Hospital, Bandung, West Java, Indonesia; ${ }^{3}$ Convalescent Plasma Therapy for \\ COVID-19 Team, Dr. Hasan Sadikin Hospital, Bandung, West Java, Indonesia; ${ }^{4}$ Department of Biology, Faculty of Medicine, \\ Maranatha Christian University, Bandung, West Java, Indonesia; ${ }^{5}$ Biomolecular and Biomedical Research Center, Aretha \\ Medika Utama, Bandung, West Java, Indonesia
}

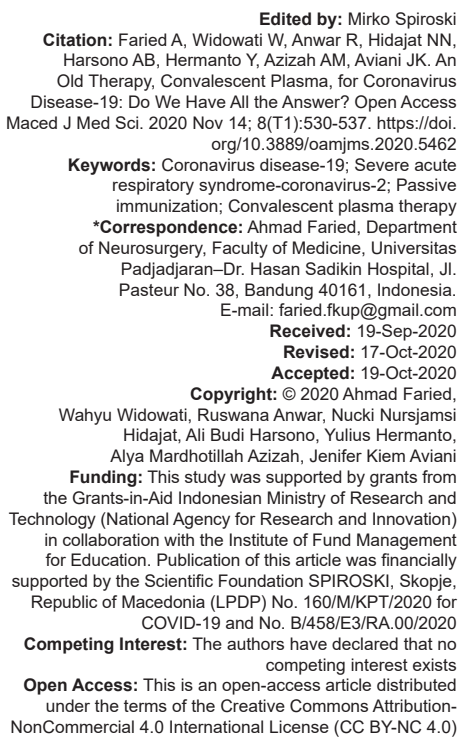

\section{Abstract}

BACKGROUND: Coronavirus (CoV) disease (COVID-19) has become a global health pandemic by early 2020; it has pushed the health-care system to its limit. From the initial estimates, 15\% of COVID-19 patients caused by severe acute respiratory CoV 2 syndrome present with severe symptoms and requires hospitalization or even intensive care. There is no specific treatment against COVID-19, particularly for those with severe symptoms. Desperation caused by COVID-19 has driven clinicians to try an alternative therapies with little or even no-evidence previously. Convalescent plasma therapy (CPT) has emerged as a promising COVID-19 therapy.

AIM: We aimed to review current state of convalescent plasma therapy.

METHODS: We summarize the historical CPT, COVID-19 pathology and evaluate potential of CPT for COVID-19; raising the question regarding routinely administrating CPT to the COVID-19 patients, whether it is safe and effective. RESULTS: From cases in Indonesia and other countries, there is bunch of examples that healthcare workers being negatively stigmatized in case of COVID-19. They lost their rights to have a normal life in this pandemic era. A reasonable basis is found in many literatures to advocate the CPT. Convalescent plasma from COVID-19 patients who had been recovered with high neutralizing antibody titers was reported to be effective on transfusion to other COVID-19 patients.

CONCLUSION: CPT is one good option to treat COVID-19 patients, but it not without risk; many potential candidate treatment that promising in theory but somehow fall apart when translated into clinical study; only time will tell, including our ongoing CPT clinical study.

\section{Introduction}

Coronavirus (CoV) disease (COVID-19) is currently a global health problem, but until recently, there is no specific therapy for COVID-19 [1]. Since December 2019, pneumonia cases caused by severe acute respiratory syndrome-CoV-2 (SARS-CoV-2) until May 24, 2020, have reported total 5,429,234 cases with 344,448 deaths and 2,259,882 recovered, with a percentage of case fatality rate (CFR) in the world of $6.48 \%$ [2]. The most cases were found in the USA with $1,667,284$ cases, followed by Brazil with 349,113 cases then Russia with 344,481 cases, while the Republic of China, where the virus originated, was in the 14 ranks with 82,974 cases. The highest death cases were in the USA which was 98,691 people, followed by the UK with 36,675 people and Italy 32,735 people; while deaths in the Republic of China reached 4,634 cases [2]. In Indonesia, as of May 24, 2020, there were 22,271 reported cases, with a total of 1372 deaths and 5402 recovered [3]. Since March 11, 2020, the World Health Organization (WHO) has established pandemic status for the COVID-19 case [4].

The COVID-19 case was first identified in Indonesia in early March 2020, which infected two patients, then spread to all provinces in Indonesia [5], [6]. The CFR rate in Indonesia reached $6.21 \%$, surpassing the Republic of China with $5.52 \%$ or even almost equal with the world $(6.48 \%)$. Patients who were confirmed positive, most came from Jakarta, which reached 6515 cases, East Java Province ranks second with 3596 cases, followed by West Java Province with 2045 cases [3]. There were 2045 positive confirmed cases in West Java Province, with recovered of 471 people and 
a death toll of 127 [3]. Until May 22, 2020, Dr. Hasan Sadikin Hospital (RSHS), Bandung, West Java, had treated 308 patients in monitoring (PIM) cases, with confirmed COVID-19 positive of 75 cases; there were 57 PIM death cases, with confirmed COVID-19 positive of 23 cases [7]. The therapy used in RSHS refers to the COVID-19 therapy protocol from the Indonesian Lung Association, including chloroquine phosphate, oseltamivir, and other supportive therapies [8].

Globally, all health authorities are planning (and constantly scrambling) for the increased growing number of hospitalized patients. With the absence of any detectable natural immunity to this CoV in the population, and no known therapy or vaccinations, management has been largely supportive to date [9]. Nevertheless, a number of therapies are being investigated and implemented by researchers and clinicians. Those clinical trials including: Retroviral drugs such as lopinavir/ritonavir and remdesivir, combination of hydroxychloroquine and azithromycin, and antimalarial drug chloroquine [10]. The other modality that has been investigated and advocated for alternative treatment of COVID-19 is convalescent plasma therapy (CPT) in the world, as well as in Indonesia [1], [11].

CPT has been known and used to preventing viral diseases such as mumps, measles, and poliomyelitis [12], [13]. This therapy also has been used effectively in the treatment of H5N1 avian influenza [14], H1N1 influenza [15], SARS [16], and Middle East respiratory syndrome (MERS) [17], in which CPT has been found to be both safe and effective. Our center in Bandung, has just started to begin the CPT clinical trial for patients with severe COVID-19 (Ethical approval No. LB.02.01/X.6.5/94/2020).

\section{SARS-CoV-2}

CoV disease 2019 (COVID-19) is a form of respiratory illness caused by severe acute respiratory syndrome CoV 2 (SARS-CoV-2); CoV is a capsulepositive, single-stranded RNA virus, included in the Coronaviridae family belong to the Orthocoronavirinae subfamily, and has a "crown-like" in its surface area [18]. CoV is included in the genus beta-CoV as (SARS; emerged in China in 2003), (MERS; appeared in Saudi Arabia in 2012) but has different biological and virulence characteristics [19]. Bats are considered as the natural host reservoir of SARS-like CoV. However, the origin or natural host for the 2019-nCoV is not clear, it might come from a kind of wild life [20]. SARS-CoV-2 is as big as $125 \mathrm{~nm}$ in diameter; they are also relatively large for the viruses that use RNA to replicate; with 30,000 genetic bases, the largest genomes of all RNA viruses. SARS-CoV-2 has 29,891 nucleotides which encode 9860 amino acids [18]. Their genomes are more than 3 times as big as those of HIV and hepatitis C, and more than twice influenza's [21]. SARS-CoV-2 is so far estimated to have a rate of $<25$ mutations per year, compare to influenza's 50 [22]. The fatality rates of both SARS and MERS are much higher, $9.6 \%$ and $34.4 \%$, respectively [23], [24]. Infographic comparison of the three major genus beta-CoV, SARS, and MERS compared to COVID-19 is shown in Figure 1.

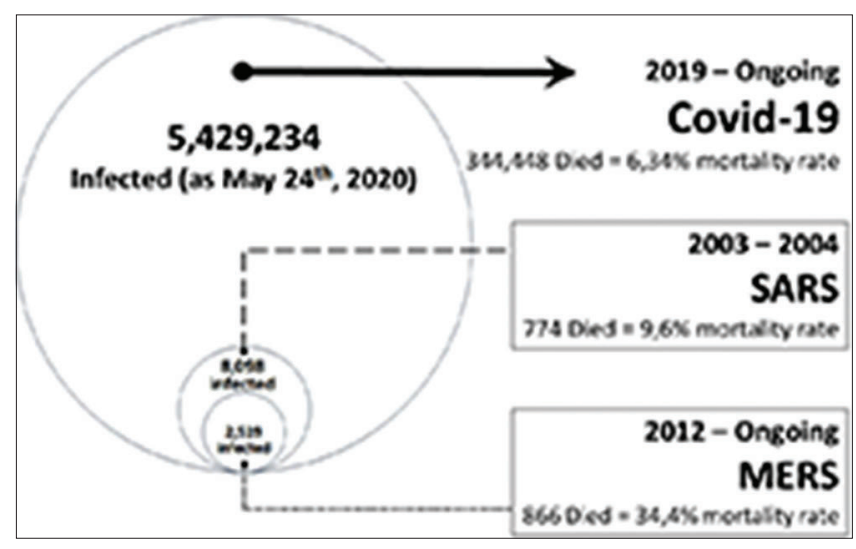

Figure 1: Infographic comparison of the three major genus betacoronavirus, namely: severe acute respiratory syndrome (emerged in China in 2002), Middle East respiratory syndrome (appeared in Saudi Arabia in 2012) and coronavirus disease 2019 (COVID-19; appeared in China in late 2019)

All CoVs contain very specific genes in open reading frame 1 (ORF1) downstream regions that encode proteins for viral replication, nucleocapsid, and spikes formation [25]. The glycoprotein spikes on the outer surface of CoVs are responsible for the attachment and entry of the virus to host cells. The receptorbinding domain (RBD) is loosely attached among virus; therefore, the virus may infect multiple hosts [26], [27]. SARS-CoV-2 possesses the typical CoV structure with spike protein and also expressed other polyproteins, nucleoproteins, and membrane proteins, such as RNA polymerase, 3-chymotrypsin-like protease, papainlike protease, helicase, glycoprotein, and accessory proteins [28], [29]. The 394 glutamine residue in the RBD region of SARS-CoV-2 is recognized by the critical lysine 31 residue on the human angiotensin converting enzyme 2 (ACE2) receptor [30]. According to current evidence, SARS-CoV-2 is primarily transmitted between the people through respiratory droplets and contact routes.

Although SARS-CoV-2 shares $79 \%$ of its genome with SARS-CoV, it presumably more contagious [31]. As recently Indonesia submitted three full sequence genome (ID: EIJK2444, EIJK 0141 and EIJK 0317) to Global Initiative on Sharing Avlan flu Data (GISAID); interestingly, all COVID-19 in Indonesia is originated from the Republic of China and been mutated as non-synonymous. For ElJK2444, travel from the Republic of China to Australia and Japan, finally arrived in Indonesia; it mutated in the amino acid Threonine at position 76, converting it to Isoleusin in the amino acid sequence of protein S. For EIJK0141, travel from the Republic of China to United Kingdom and United State, and finally arrived in Indonesia; it mutated in the amino acid Serine at position 2103, converting it to Phenilalanine in the amino acid sequence of protein ORF1a. For EIJK0317, travel from the Republic of China to United 
Kingdom, United State and United Arab Emirates, and finally arrived in Indonesia; it mutated in the amino acid Isoleucine at position 461, converting it to Valine in the amino acid sequence of protein ORF1a [32].

Both of SARS-CoVs enter the host cells through ACE2 receptor [30]. The SARS-CoV-2 predominantly infects the lower airways and binds to ACE2 on surface alveolar epithelial cells. Both viruses are potent inducers of inflammatory cytokines. The cytokine storm or cytokine cascade is the postulated mechanism for organ damage. The virus activates immune cells, induces the secretion of inflammatory cytokines and chemokines into pulmonary vascular endothelial cells [33]. There were 14 cytokines that significantly elevated on admission in COVID-19 cases. Moreover, IP-10, MCP-3, and IL-1ra were significantly higher in severe cases and highly associated with the $\mathrm{PaO}_{2} / \mathrm{FaO}_{2}$ and Murray score [34].

\section{Pathology of COVID-19}

The $\mathrm{S}$ protein on CoV surface specifically recognizes the spike protein in ACE2 of the exposed cell and after binding, the virus enters the cell thereby infected the cell [30]. Unfortunately, the ACE2 receptor is widely distributed on the human cells surface, especially at AT2 (alveolar cell type II) of the lungs. ACE2 receptors are also abundantly found in the heart, liver, digestive organs, and kidneys. In fact, almost all endothelial and smooth muscle cells in our organ express ACE2; therefore, once virus enters the blood circulation, it spreads widely in the body [35]. All tissues and organs expressing ACE2 could be "the battlefield" of the CoV against immune cells. Based on Huang et al., (2020), most COVID-19 patients presented with dry cough, fever, dyspnea, and bilateral ground-glass opacities on chest computed tomography scans [20]. These COVID-19 infection characteristics bear a certain resemblance to SARS and MERS infections [36], [37] However, few patients with COVID19 infection had prominent upper respiratory tract signs and symptoms (such as rhinorrhea, sneezing, or sore throat), indicating that the target cells may be located in the lower airway. Based on Indonesian task force for COVID-19, most death cases related to airway problem (cough 17.3\% and breathing difficulties 14.7\%) [3]. Further, COVID-19 patients rarely developed intestinal signs and symptoms (like diarrhea), whereas about $20-25 \%$ of patients with SARS or MERS infection had diarrhea [20], [37]; in Indonesia about 7.6-8.2\% [3]. In severe form of COVID-19, CoV infection stimulates a cytokine storm that lead to acute respiratory distress syndrome (ARDS), acute cardiac injury, and secondary infection that lead to generalized sepsis thus multiorgan failure, which eventually lead to death [38]. Avoiding

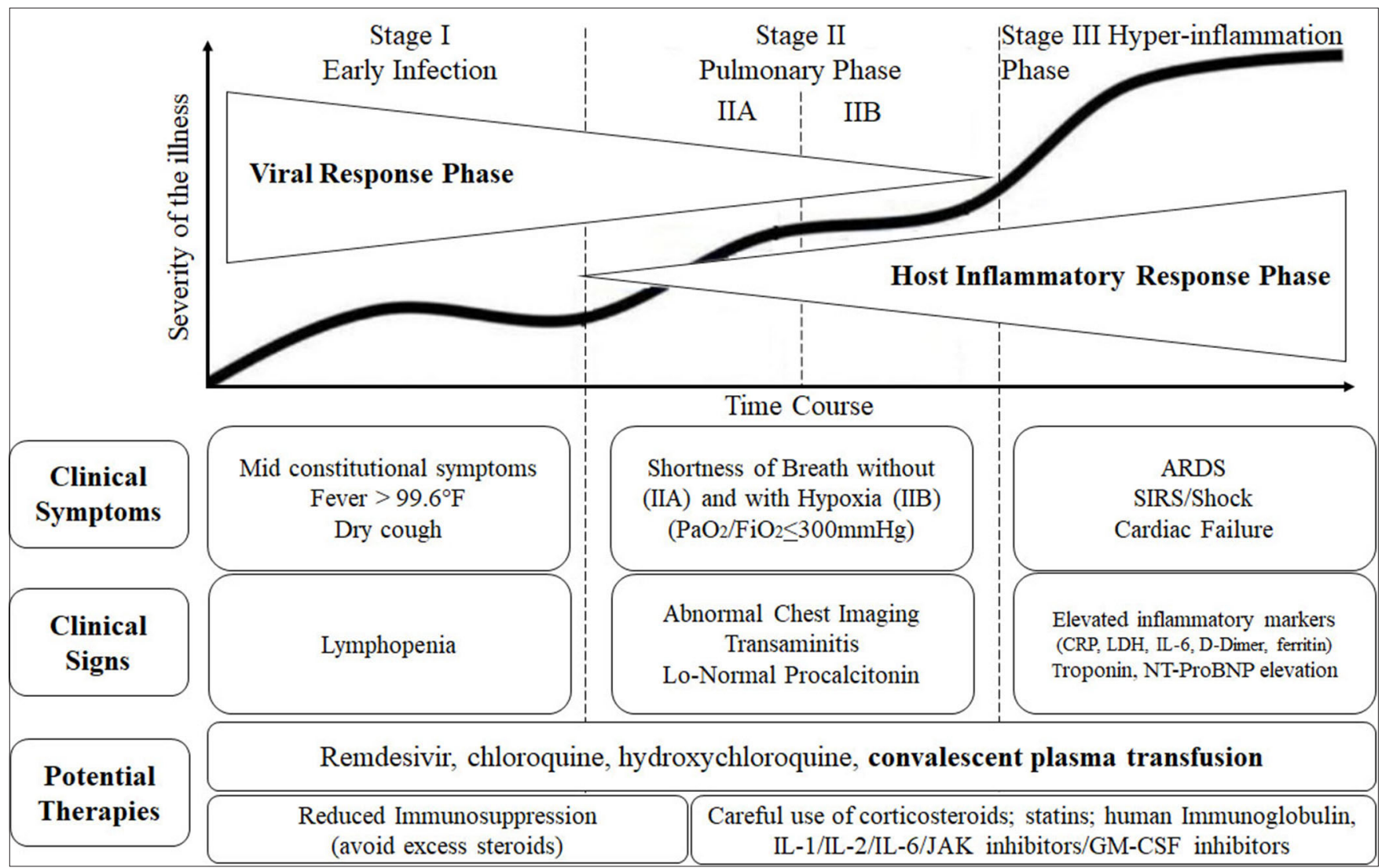

Figure 2: Three-stage classification system proposed by Siddiqi HK and Mehra MR [39], recognizing that coronavirus disease-19 illness exhibits three grades of increasing severity, which correspond with distinct clinical findings, response to therapy, and clinical outcome 
or modulating the cytokine storm maybe the key for treatment of severe/critical patients with COVID-19 summarized in Figure 2 [39].

\section{CPT}

Desperation caused by COVID-19, the high mortality rate caused by ARDS that has not been successfully cured with conventional therapy and the increasing need for intensive care unit due to its accelerating number of ARDS sufferers has driven clinicians to try an alternative therapies with little or even no-evidence therapy previously (e.g., herbal medicine, cell-based therapy, and CPT). Convalescent plasma is a treatment that known for more than 100 years ago that the $1^{\text {st }}$ time described in JAMA in 1893, when the German scientists used the serum from animal immunized against diphtheria to treat patients with the disease [21]. CPT also had been used against the 1918 Spanish flu pandemic, measles, MERS, Ebola, and SARS [21]. CPT is considered as out-of-dated approach for modern diseases, such as COVID-19, compared with all the advanced technologies in medicine and the entire novel breakthrough in molecular biology that we know today.

CPT has emerged as a potential therapy for patients with severe COVID-19. The principle of CPT is to use antibodies from the healthy people who had recovered from COVID-19 (a.k.a convalescent); as antibody-rich in their plasma to provide neutralizing effects for high viral load and to calm down the cytokine storm in patients with severe COVID-19. CPT is particularly encouraged to utilize in patients with severe COVID-19 (ARDS) those have no other "effective" treatment. CPT are useful against emerging infectious agents if the latter induces neutralizing antibodies [40]. The effectiveness of CPT appears to differ depending on the pathogen and treatment protocols (e.g., timing, volume, and dosing of administration) [41]. CPT is not a novel concept. It has been applied to the prevention and treatment of many infectious diseases. The successful of $\mathrm{CPT}$ to treat the severe acute viral respiration infections brings optimism in the management of the COVID19 [12]. A meta-analysis from 32 studies of SARS and severe influenza showed a statistically significant reduction in the pooled odds of mortality following CPT, compared with placebo or no therapy (odds ratio, 0.25 ; $95 \% \mathrm{Cl}$ ) [40]. In 2014, the WHO suggested the use of CP obtained from patients recovering from Ebola virus disease (EVD) as an empirical treatment during outbreaks [42]; unfortunately, CPT was not associated with a significant improvement in survival for EVD. Recently, in 2019, there was published one report for randomized clinical trial (RCT) of 140 children and adults with influenza treated either CPT with high level of anti-influenza antibodies or to standard plasma. Those double-blind study concluded that the antiinfluenza CPT coffered no significant benefit superior versus standard plasma [43].

\section{The Principle of Convalescent Blood} Products Administration

After 10-14 days of infections usually followed by the clearance of viremia, this was the principle of convalescent blood products administration that usually performed after the initial symptoms to maximize efficacy [16]. Concurrent treatments might synergize or antagonize CPT efficacy (e.g., polyclonal intravenous immunoglobulins or steroids) [44]. Since the virological and clinical characteristics share similarity among SARS, MERS, and COVID-19, CPT might be a promising treatment option for COVID-19 rescue. The most critically ill patients show prolonged viremia (strongly correlated with serum IL-6 levels) which leaves room for the therapeutic intervention with antivirals and immunoglobulins even in late stages [45]. Viral shedding in survivors can be as long as 37 days, mandating SARSCoV-2 RNA screening in CP donors [46]. Appearance of serum IgM and IgA antibody in COVID-19 occurs since day 5 after symptom onset, while IgG is detected since day 14 but universally detected since day 20 [47], [48]. Severe female patients generate IgG earlier and higher titers [49]. The reason remains unknown but this could be detrimental consequences clinically; more chance of having transfusion-related acute lung injury (TRALI). Hence, the patients with resolved SARS-CoV-2 viral infection will develop significant serum antibody response (lgG) to different viral epitopes of the SARS-CoV-2 virus and some of these developed antibody responses in the host system will be likely to have the potential to neutralize the virus [12]. There is, currently, no evidence that people who have recovered from COVID-19 and have antibodies are protected from a second infection, as reported in china that seven cases of COVID-19 (three children and four adults) who was readmitted to hospital after recovered from COVID-19 [50]; as such issue rising the important to determining the efficacy of CPT.

The high level of antibody titers produced by the host immune system against the SARS-CoV-2 virus significantly reduces the chances of getting re-infected [12]. Patients who have recovered from COVID-19 with a high neutralizing antibody titer may be a valuable donor source of CPT (1). However, duration of anti-SARS-CoV-2 antibodies in plasma remains unknown, though for other beta-CoVs immunity typically lasts 6-12 months [51]. Hence, a suitable donor could donate $600 \mathrm{~mL}$ plasma (equivalent to three therapeutic doses) every 14 days for a minimum of 6 months. In contrast to EVD, SARS, and MERS, most of COVID19 patients exhibit few or no symptoms and do not require hospitalization, suggesting that the majority of convalescent donors are best sought after in the general population [52]. Based on Indonesian COVID-19 CPT Task Force 2020, the appropriate donor [53], [54] and recipient [55] must meet the following conditions: 


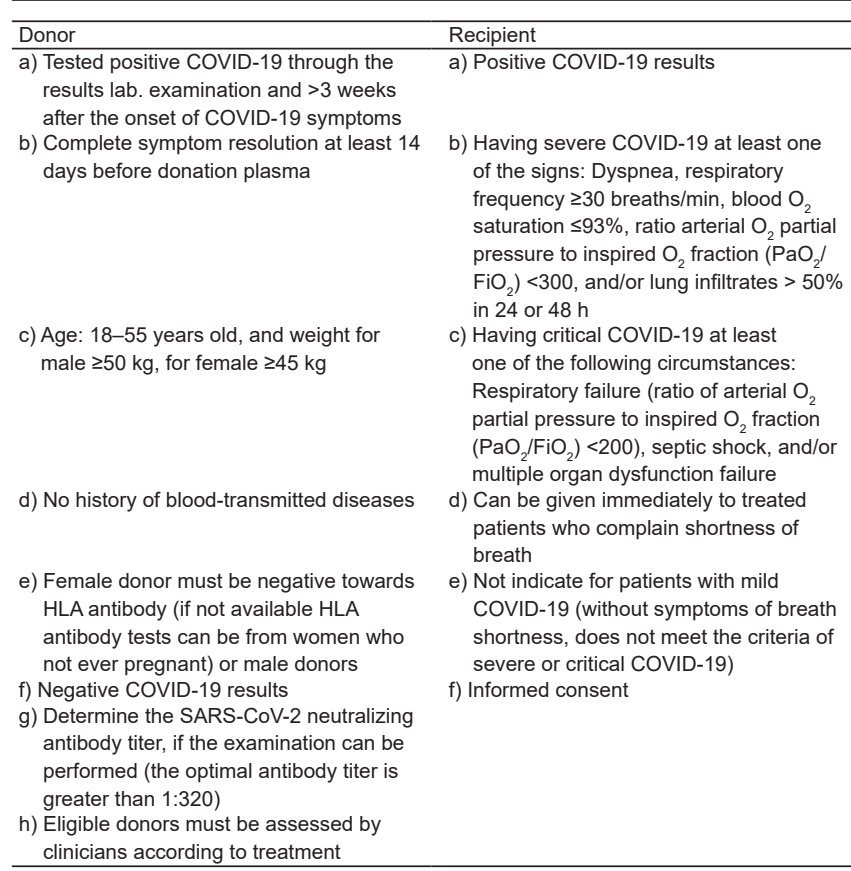

Based on Pei et al., (2020), CP was collected using fully automatic apheresis machine or a fully automatic blood cell separator (refer to technical operation procedure of blood station). The plasma volume taken was around $200-400 \mathrm{~mL}$ that the exact volume should be assessed by clinicians. The interval between plasma collections should be more than 2 weeks. The plasma was stored at $2-6^{\circ} \mathrm{C}$ for $48 \mathrm{~h}$, while for long-term storage; it should be rapidly frozen at $-20^{\circ} \mathrm{C}$.

\section{CPT, Do We Have All the Answer?}

The first published report of CPT against COVID-19, a preliminary communication posted online on March 27, 2020, in JAMA for five seriously ill patients in China. Shen et al., (2020), reported in all five patients, who were critically ill with COVID-19, after treated with CPT shown the body temperature normalized within 3 days in four of five patients, the Sequential Organ Failure Assessment score decreased, and $\mathrm{PaO}_{2} / \mathrm{FiO}_{2}$ increased within 12 days (around 172-276 before treatment and 284-366 after treatment) [56]. Furthermore, viral loads decreased and became negative within 12 days of transfusion and SARS-CoV-2-specific ELISA and neutralizing antibodies titers increased after the transfusion (around 40-60 before treatment and 80-320 after treatment on day 7). Furthermore, at 12 days after transfusion, ARDS was resolved in four patients. Within 2 weeks of treatment, three patients were weaned from mechanical ventilation. From five patients, three patients have been discharged from hospital (length of stay: 53,51 , and 55 days) and two patients are in stable condition at 37 days after transfusion. Two more reports from Wuhan, published on April 6 and April 15, 2020, respectively [1], [57]. All those reported the therapy save lives and looking for continuing with randomized controlled trial to confirm the results.

The US Food and Drug Administration (FDA) first announce on March 24, 2020; in more details on April 3, and April 13, 2020, respectively, that FDA would facilitate access to CP for treating COVID-19. The FDA cautioned "It is therefore important to determine through clinical trials, before routinely administrating CPT to the patient with COVID-19, that it is safe and effective." CPT is one good option, but it not without risk. The COVID-19 may cause increasing clotting; Plasma is rich with clotting factors and typically used to reverse bleeding problems, so theoretically CPT could increase clotting risk in patients with COVID-19 without any promise of benefit (plasma also promote anti-coagulation) [58]. In additional, plasma transfusion is also associated with adverse event, ranging from mild fever and allergic reaction (e.g., plasma protein, sodium citrate, or selective $\lg A$ deficiency) to lifethreatening bronchospasm, TRALI (male donors are usually preferred to avoid the risk of transfusing anti-HLA/HNA/HPA antibodies from parous women; as anti-HLA/HNA/HPA antibody screening should be performed), and antibody-dependent enhancement that will leads to enhanced infection and transfusion associated circulatory overload (TACO) such as in patients with cardiorespiratory disorder, old age, or renal impairment [59]; also chance the risk of transfusion-transmitted infectious (TTI), as pathogen inactivation combine with nucleic acid testing can reduced TTIs.

There is a lack of RCTs investigating CPT as a potential therapy for COVID-19, though observational studies have reported some promising benefits. There were two RCTs [60], [61], that were published after being terminated early. The first RCT was conducted in Wuhan, China, February to April 2020. It was comparing the standard treatment $(n=52)$ versus the effect of CPT ( $n=51)$; with two patients reported an adverse events [60]. Ultimately, there was no significant effect of CPT on the primary outcome of time to clinical improvement within 28 days [60]. The second RCT, conducted in the Erasmus MC, Netherlands [61]. It was comparing the standard treatment $(n=43)$ versus the effect of CPT ( $n=43)$; hence, somewhat unsurprisingly, there was no effect of treatment on mortality, hospital length of stay or disease severity [61].

In addition, an initial safety assessment of 5000 patients who received CPT in the USA demonstrated a $0.08 \%$ mortality, $0.14 \%$ TACO, 0.22 TRALI, and $0.06 \%$ severe allergic transfusion reaction; with over all $<1 \%$ rate of serious adverse events immediately following treatment, indicating that the risks of CPT are likely not excessive relative to the risks of severe COVID19 [62]. Another larger study of 138 CPT patients who were compared with 1430 patients receiving standard therapy showed promising benefits such as reduced mortality and reduced proportion of patients exhibiting 
shortness of breath, somehow there were three patients experienced minor allergic [63]. Despite the above studies reporting positive and negatives outcomes, pro versus contra; it is clear that additional RCTs and global action are required.

\section{Conclusion}

There are so many of potential candidate treatment that are so promising in theory but somehow fall apart when translated into real-clinical study; only time will tell, including our ongoing CPT clinical study. All of these CPT against a massively COVID-19 infection is "imperfect Science," and YES, we do not have all the answer; but its' worth to trying rather than dying doing nothing.

\section{Acknowledgments}

The authors would like to give special thanks to RSHS-COVID-19 Team, Bandung, for their daily devotions on this pandemic. Also to the Universitas Padjadjaran (UNPAD), Bandung, especially Faculty of Medicine, for their technical assistance to publishing this review.

\section{Availability of Data and Materials Section}

The datasets gathered and shown in this review is available as an open access data as cited in our references; the corresponding author will make it available on reasonable request.

\section{Authors' Contributions}

$\mathrm{AF}, \mathrm{RA}, \mathrm{WW}, \mathrm{YH}, \mathrm{NNH}$, and $\mathrm{ABH}$ design the discussion directions. AMA and JKA gathering all the data and references. All authors took part on writing and approved of the final manuscript.

\section{References}

1. Duan K, Liu B, Li C, Zhang H, Yu T, Qu J, et al. Effectiveness of convalescent plasma therapy in severe COVID-19 patients. Proc Natl Acad Sci USA. 2020;117(17):9490-6.

\section{PMid:32253318}

2. World Health Organization. Coronavirus Disease 2019 (COVID19) Dashboard; 2020. Available from: https://www.covid19.who. int. [Last accessed on 2020 May 24].

3. Gugus Tugas Percepatan Penanganan COVID-19, Data Sebaran; 2020. Available from: https://www.covid19.go.id. [Last accessed on 2020 May 24].

4. Chang L, Yan Y, Wang L. Coronavirus disease 2019: Coronaviruses and blood safety. Transfus Med Rev. 2020;34(2):75-80.

PMid:32107119

5. Worldmeter. COVID-19 Coronavirus Pandemic: Worldmeter 2020. Available from: https://www.worldometers.info/ coronavirus/? [Last accessed on 2020 May 24].

6. Rokom. Pasien Positif COVID-19 Bertambah 2 Orang. Jakarta: Kementrian Kesehatan Republik Indonesia; 2020. Available from: $\quad$ http://www.sehatnegeriku.kemkes.go.id/baca/rilismedia/20200306/1533247/pasien-positif-covid-19-bertambah2-orang. [Last accessed on 2020 Mar 06].

7. Pusat Data COVID-19 RSHS, Bandung; 2020. Available from: http://www.web.rshs.or.id/data-odp-dan-pdp-covid-19-6mei-2020. [Last accessed on 2020 May 22].

8. Tatalaksana Pasien COVID-19. Perhimpunan Dokter Paru Indonesia; 2020. Available from: http://www.klikpdpi.com. [Last accessed on 2020 Apr 10].

9. Sullivan HC, Roback JD. Convalescent plasma: Therapeutic hope or hopeless strategy in the SARS-CoV-2 pandemic Transfus Med Rev. 2020;34(3):145-50. https://doi.org/10.1016/j. tmrv.2020.04.001 PMid:32359788

10. Rosa SG, Santos WC. Clinical trials on drug repositioning for COVID-19 treatment. Rev Panam Salud Publica. 2020;44:e40. https://doi.org/10.26633/rpsp.2020.40 PMid:32256547

11. Monica Th, Triyono T, Harly PR. Penatalaksanaan Terapi Plasma Konvalesen (TPK) Bagi Pasien COVID-19. Indonesia: Tim TPK COVID-19; 2020

12. Anudeep TC, Jeyaraman M, Shetty DU, Raj MH, Ajay SS, Somasundaram $\mathrm{R}$, et al. Convalescent plasma as a plausible therapeutic option in nCOVID-19-a review. J Clin Trials. 2020;10:409.

13. Casadevall A, Pirofski LA. The convalescent sera option for containing COVID-19. J Clin Invest. 2020;130(4):1545-8. https:// doi.org/10.1172/jci138003 PMid:32167489

14. Zhou B, Zhong N, Guan Y. Treatment with convalescent plasma for influenza $A$ (H5N1) infection. $N$ Engl J Med. 2007;357(14):1450-1. https://doi.org/10.1056/nejmc070359 PMid:17914053

15. Hung IF, To KK, Lee CK, Lee KL, Chan K, Yan WW, et al Convalescent plasma treatment reduced mortality in patients with severe pandemic influenza A (H1N1) 2009 virus infection. Clin Infect Dis. 2011;52(4):447-56. PMid:21248066

16. Cheng $\mathrm{Y}$, Wong $\mathrm{R}$, Soo $\mathrm{YO}$, Wong WS, Lee $\mathrm{CK}, \mathrm{Ng} \mathrm{MH}$, et al Use of convalescent plasma therapy in SARS patients in Hong Kong. Eur J Clin Microbiol Infect Dis. 2005;24(1):44-6. https:// doi.org/10.1007/s10096-004-1271-9

PMid:15616839

17. Ko JH, Seok H, Cho SY, Ha YE, Baek JY, Kim SH, et al Challenges of convalescent plasma infusion therapy in Middle East respiratory Coronavirus infection: A single centre experience. Antivir Ther. 2018;23(7):617-22. https://doi. org/10.3851/imp3243

PMid:29923831 
18. Cascella M, Rajnik M, Cuomo A, Dulebohn SC, Napoli RD. Features, Evaluation and Treatment Coronavirus. Treasure Island, FL: Stat Pearls Publishing; 2020.

19. Wu YC, Chen CS, Chan YJ. The outbreak of COVID-19: An overview. J Chin Med Assoc. 2020;83(3):217-20. PMid:32134861

20. Huang C, Wang Y, Li X, Ren L, Zhao J, Hu Y, et al. Clinical features of patients infected with 2019 novel Coronavirus in Wuhan, China. Lancet. 2020;395(10233):497-506.

\section{PMid:31986264}

21. Cyranoski D. Profile of a killer: The complex biology powering the Coronavirus pandemic. Nature. 2020;581(7806):22-6. https://doi.org/10.1038/d41586-020-01315-7 PMid:32367025

22. Korber B, Fischer WM, Gnanakaran S, Yoon H, Theiler J, Abfalterer W, et al. Spike Mutation Pipeline Reveals the Emergence of a More Transmissible form of SARS-CoV-2, bioRxiv; 2020. https://doi.org/10.1101/2020.04.29.069054

23. Munster VJ, Koopmans M, van Doremalen N, van Riel D, de Wit E. A novel Coronavirus emerging in China-key questions for impact assessment. N Engl J Med. 2020;382(8):692-4. https:// doi.org/10.1056/nejmp2000929

PMid:31978293

24. Chen J. Pathogenicity and transmissibility of 2019-nCoV-a quick overview and comparison with other emerging viruses. Microbes Infect. 2020;22(2):69-71. https://doi.org/10.1016/j. micinf.2020.01.004

PMid:32032682

25. van Boheemen S, de Graaf M, Lauber C, Bestebroer TM, Raj VS, Zaki AM, et al. Genomic characterization of a newly discovered Coronavirus associated with acute respiratory distress syndrome in humans. mBio. 2012;3(6):e00473-12. https://doi.org/10.1128/mbio.00473-12

PMid:23170002

26. Raj VS, Mou H, Smits SL, Dekkers $D H$, Müller MA, Dijkman R, et al. Dipeptidyl peptidase 4 is a functional receptor for the emerging human Coronavirus-EMC. Nature. 2013;495(7440):251-4. https://doi.org/10.1038/nature12005 PMid:23486063

27. Perlman S, Netland J. Coronaviruses post-SARS: Update on replication and pathogenesis. Nat Rev Microbiol. 2009;7(6):43950. https://doi.org/10.1038/nrmicro2147 PMid: 19430490

28. Wu F, Zhao S, Yu B, Chen YM, Wang W, Song ZG, et al. A new Coronavirus associated with human respiratory disease in China. Nature. 2020;579(7798):265-9.

PMid:32015508

29. Zhou P, Yang X, Wang X, Hu B, Zhang L, Zhang W, et al. A pneumonia outbreak associated with a new Coronavirus of probable bat origin. Nature. 2020;579(7798):270-3. PMid:32015507

30. Wan Y, Shang J, Graham R, Baric RS, Li F. Receptor recognition by the novel Coronavirus from Wuhan: An analysis based on decade-long structural studies of SARS Coronavirus. J Virol. 2020;94(7):e00127-20. https://doi.org/10.1128/jvi.00127-20 PMid:31996437

31. de Wit E, van Doremalen N, Falzarano D, Munster VJ. SARS and MERS: Recent insights into emerging Coronaviruses. Nat Rev Microbiol. 2016;14(8):523-34. https://doi.org/10.1038/ nrmicro.2016.81

PMid:27344959

32. Global Initiative on Sharing Avian Flu Data (GISAID). Genomic Epidemiology of hCoV-19; 2020. Available from: https://www. gisaid.org/epiflu-applications/next-hcov-19-app. [Last accessed on 2020 Sep 02].

33. Jiang F, Deng L, Zhang L, Cai Y, Cheung CW, Xia Z. Review of the clinical characteristics of Coronavirus disease 2019 (COVID-19). J Gen Intern Med. 2020;35(5):1545-9. https://doi. org/10.1007/s11606-020-05762-w PMid:32133578

34. Yang Y, Shen C, Li J, Yuan J, Yang M, Wang F, et al. Exuberant Elevation of IP-10, MCP-3 and IL-1ra During SARS-CoV-2 Infection is Associated with Disease Severity and Fatal Outcome, medRxiv; 2020. https://doi.org/10.1101/2020.03.02.20029975

35. Leng $Z$, Zhu R, Hou W, Feng $Y$, Yang $Y$, Han $Q$, et al Transplantation of ACE2-mesenchymal stem cells improves the outcome of patients with COVID-19 pneumonia. Aging Dis. 2020;11(2):216-28

PMid:32257537

36. Lee N, Hui D, Wu A, Chan P, Cameron P, Joynt GM, et al. A major outbreak of severe acute respiratory syndrome in Hong Kong. N Engl J Med. 2003;348(20):1986-94. https://doi.org/10.1056/ nejmoa030685

PMid:12682352

37. Assiri A, Al-Tawfiq JA, Al-Rabeeah AA, Al-Rabiah FA, Al-Hajjar S, Al-Barrak A, et al. Epidemiological, demographic, and clinical characteristics of 47 cases of Middle East respiratory syndrome Coronavirus disease from Saudi Arabia: A descriptive study. Lancet Infect Dis. 2013;13(9):752-61. https://doi.org/10.1016/ s1473-3099(13)70204-4

PMid:23891402

38. Guzik TJ, Mohiddin SA, Dimarco A, Patel V, Savvatis K, MarelliBerg FM, et al. COVID-19 and the cardiovascular system: Implications for risk assessment, diagnosis, and treatment options. Cardiovasc Res. 2020;116(10):1666-87. https://doi. org/10.1093/cvr/cvaa106

PMid:32352535

39. Siddiqi HK, Mehra MR. COVID-19 illness in native and immunosuppressed states: A clinical-therapeutic staging proposal. J Heart Lung Transplant. 2020;39(5):405-7. https:// doi.org/10.1016/j.healun.2020.03.012

PMid:32362390

40. Mair-Jenkins J, Saavedra-Campos M, Baillie JK, Cleary P, Khaw FM, Lim WS, et al. The effectiveness of convalescent plasma and hyperimmune immunoglobulin for the treatment of severe acute respiratory infections of viral etiology: A systematic review and exploratory meta-analysis. J Infect Dis. 2015;211(1):80-90. https://doi.org/10.1093/infdis/jiu396 PMid:25030060

41. Brown BL, McCullough J. Treatment for emerging viruses: Convalescent plasma and COVID-19. Transfus Apher Sci. 2020;59(3):102790. https://doi.org/10.1016/j. transci.2020.102790

PMid:32345485

42. World Health Organization. Use of Convalescent Whole Blood or Plasma Collected from Patients Recovered from Ebola Virus Disease No. WHO/HIS/SDS/2014.8. Geneva: World Health Organization; 2014. p. 1-19.

43. Davey RT, Fernández-Cruz E, Markowitz N, Pett S, Babiker AG, Wentworth $\mathrm{D}$, et al. Anti-influenza hyperimmune intravenous immunoglobulin for adults with influenza A or B infection (FLUIVIG): A double-blind, randomised, placebo-controlled trial. Lancet Respir Med. 2019;7(11):951-63.

PMid:31582358

44. Luke TC, Kilbane EM, Jackson JL, Hoffman SL. Meta-analysis: Convalescent blood products for Spanish influenza pneumonia: A future H5N1 treatment? Ann Intern Med. 2006;145(8):599-609. https://doi.org/10.7326/0003-4819-145-8-200610170-00139 PMid:16940336 
45. Chen X, Zhao B, Qu Y, Chen Y, Xiong J, Feng $Y$, et al. Detectable Serum SARS-CoV-2 Viral Load (RNAaemia) is Closely Associated with Drastically Elevated Interleukin 6 (IL-6) Level in Critically III COVID-19 Patients, medRxiv; 2020. https:// doi.org/10.1101/2020.02.29.20029520

46. Zhou F, Yu T, Du R, Fan G, Liu Y, Liu Z, et al. Clinical course and risk factors for mortality of adult inpatients with COVID-19 in Wuhan, China: A retrospective cohort study. Lancet. 2020;395(10229):1054-62. https://doi.org/10.1016/ s0140-6736(20)30566-3

\section{PMid:32171076}

47. Guo L, Ren L, Yang S, Xiao M, Chang, Yang F, et al. Profiling early humoral response to diagnose novel Coronavirus disease (COVID-19). Clin Infect Dis. 2020;71(15):778-85. https://doi. org/10.1093/cid/ciaa310

PMid:32198501

48. Long QX, Deng HJ, Chen J, Hu J, Liu BZ, Liao P, et al. Antibody Responses to SARS-CoV-2 in COVID-19 Patients: The Perspective Application of Serological Tests in Clinical Practice, medRxiv; 2020.

49. Zeng F, Dai C, Cai P, Wang J, Xu L, Li J, et al. A Comparison Study of SARS-CoV-2 IgG Antibody Between Male and Female COVID-19 Patients: A Possible Reason Underlying Different Outcome Between Gender, medRxiv; 2020. https://doi. org/10.1101/2020.03.26.20040709

50. Zhang B, Liu S, Dong Y, Zhang L, Zhong Q, Zou Y, et al. Positive rectal swabs in young patients recovered from Coronavirus disease 2019 (COVID-19). J Infect. 2020;81(2):e49-52. https:// doi.org/10.1016/j.jinf.2020.04.023

PMid:32335176

51. Chan KH, Cheng VC, Woo PC, Lau SK, Poon LL, Guan Y, et al. Serological responses in patients with severe acute respiratory syndrome Coronavirus infection and cross-reactivity with human coronaviruses 229E, OC43, and NL63. Clin Diagn Lab Immunol. 2005;12(11):1317-21. https://doi.org/10.1128/ cdli.12.11.1317-1321.2005 PMid: 16275947

52. Focosi D, Tang J, Anderson A, Tuccori M. Convalescent Plasma Therapy for COVID-19: State of the Art, Preprints 2020. https:// doi.org/10.20944/preprints202004.0097.v7

53. Franchini M, Marano G, Velati C, Pati I, Pupella S, Liumbruno GM. Operational protocol for donation of antiCOVID-19 convalescent plasma in Italy. Vox Sang. 2020 https://doi.org/10.1111/vox.12940

PMid:32324899
54. Pei S, Yuan $X$, Zhang ZZ, Yao RR, Xie Y, Shen MM, et al. Convalescent Plasma to Treat COVID-19: Chinese Strategy and Experiences, medRxiv; 2020. https://doi. org/10.1101/2020.04.07.20056440

55. Monica Th, Triyono T, Harly PR. Penatalaksanaan Terapi Plasma Konvalesen Bagi Pasien COVID-19, Tim TPK COVID19 Indonesia; 2020.

56. Shen C, Wang Z, Zhao F, Yang Y, Li J, Yuan J, et al. Treatment of 5 critically III patients with COVID-19 with convalescent plasma. JAMA. 2020;323(16):1582-9. PMid:32219428

57. Ye M, Fu D, Ren Y, Wang F, Wang D, Zhang F, et al. Treatment with convalescent plasma for COVID-19 patients in Wuhan, China. J Med Virol. 2020.

PMid:32293713

58. Yazer MH. The how's and why's of evidence based plasma therapy. Korean J Hematol. 2010;45(3):152-7. https://doi. org/10.5045/kjh.2010.45.3.152

PMid:21120202

59. Leider JP, Brunker PA, Ness PM. Convalescent transfusion for pandemic influenza: Preparing blood banks for a new plasma product? Transfusion. 2010;50(6):1384-98. https://doi. org/10.1111/j.1537-2995.2010.02590.x PMid:20158681

60. Li L, Zhang W, Hu Y, Tong X, Zheng S, Yang J, et al. Effect of convalescent plasma therapy on time to clinical improvement in patients with severe and life-threatening COVID-19: A randomized clinical trial. JAMA. 2020;324(5):460-70. https://doi. org/10.1001/jama.2020.12607

PMid:32492084

61. Gharbharan A, Jordans CC, Geurtsvankessel C. Convalescent Plasma for COVID-19. A Randomized Clinical Trial, medRxiv; 2020.

62. Joyner MJ, Wright RS, Fairweather D, Senefeld JW, Bruno KA, Klassen SA, et al. Early safety indicators of COVID19 convalescent plasma in 5, 000 patients. J Clin Invest. 2020;130(9):4791-7.

PMid:32525844

63. Enzmann MO, Erickson MP, Grindeland CJ, Lopez SM, Hoover SE, Leedahl DD. Treatment and preliminary outcomes of 150 acute care patients with COVID-19 in a rural health system in the Dakotas. Epidemiol Infect. 2020;148:e124. https:// doi.org/10.1017/s0950268820001351

PMid:32605683 